\title{
The Enterococcus hirae R40 penicillin-binding protein 5 and the methicillin-resistant Staphylococcus aureus penicillin-binding protein $2^{\prime}$ are similar
}

\author{
Aboubaker EL KHARROUBI,* Philippe JACQUES,* Graziella PIRAS,* Jozef VAN BEEUMEN, $\dagger$ \\ Jacques COYETTE* $\ddagger$ and Jean-Marie GHUYSEN* \\ *Centre d'Ingénierie des Protéines, Université de Liège, Institut de Chimie, B6, B-4000 Sart Tilman (Liège 1), Belgium, and \\ $\nmid$ Laboratorium voor Microbiologie en Microbiële Genetica, Rijksuniversiteit-Gent, Ledeganckstraat 35, B-9000 Gent, Belgium
}

\begin{abstract}
The penicillin-resistant Enterococcus hirae R40 has a typical profile of membrane-bound penicillin-binding proteins (PBPs) except that the $71 \mathrm{kDa}$ PBP5 of low penicillin affinity represents about $50 \%$ of all the PBPs present. Water-soluble tryptic-digest peptides were selectively produced from PBP5, their $\mathrm{N}$-terminal regions were sequenced and synthetic oligonucleotides were used as primers to generate a 476 bp DNA fragment by polymerase chain reaction. On the basis of these data, the PBP5-encoding gene was cloned in Escherichia coli by using pBR322 as vector. The gene, included in a $7.1 \mathrm{~kb}$ insert, had the information for a 678-amino acid-residue protein. PBP5 shows similarity, in the primary structure, with the high-molecular-mass PBPs of class B. In particular, amino acid alignment of the enterococcal PBP5 and the methicillin-resistant staphylococcal PBP2' generates scores that are 30, for the $N$-terminal domains, and 53, for the $C$ terminal domains, standard deviations above that expected for a run of 20 randomized pairs of proteins having the same amino acid compositions as the two proteins under consideration.
\end{abstract}

\section{INTRODUCTION}

Bacteria possess multiple membrane-bound proteins that bind penicillin in the form of stable serine-ester-linked penicilloyl derivatives [1]. The penicillin-binding proteins (PBPs) fall in two major groups. The monofunctional low-molecular-mass PBPs are active-site-serine DD-peptidases; they probably control the extent of wall peptidoglycan cross-linking. The high-molecularmass PBPs are two-domain proteins in which the active-siteserine-containing penicillin-binding $C$-terminal domain is preceded by a several-hundred-amino acid-residue $N$-terminal extension [1,2]. They fulfil multiple functions. In Bacillus licheniformis the high-molecular-mass PBP BLAR is the penicillin sensory-transducer required for the specific inducibility of $\beta$ lactamase synthesis [3,4]. PBPs 1A and 1B of Escherichia coli catalyse peptidoglycan transglycosylation (presumably at a site in the $\mathrm{N}$-terminal domain) and peptidoglycan transpeptidation (presumably at the serine-containing site of the $C$-terminal domain) [2]. PBPs 2 and 3 of Esch. coli, in conjunction with other life-cycle proteins, play important roles in cell division and determination of cell shape [1,2,5-9].

Resistance to $\beta$-lactam antibiotics may arise by the acquisition of a novel PBP of low penicillin affinity, for example the PBP2' of Staphylococcus aureus [10-12], or by the introduction of multiple amino acid substitutions resulting in the remodelling of the penicillin-binding domain of some targeted high-molecularmass PBPs, for example the PBPs 3 of Escherichia coli [13], 2B and 2X of Streptococcus pneumoniae [14-16] and 2 of Neisseria gonorrhoeae and Neisseria meningitidis [17-20]. Sequence-similarity searches suggest that these high-molecular-mass PBPs are related to each other and probably form a distinct class B of PBPs of great physiological importance $[1,16]$.

The relatively low susceptibility to penicillin of Enterococcus hirae A.T.C.C. 9790 [21] and Ent. hirae S185, a clinical isolate from pig intestine [22], has been attributed to the presence of a high-molecular-mass PBP of low affinity for the drug, the $71 \mathrm{kDa}$ PBP5 and the $77 \mathrm{kDa}$ PBP3 ${ }^{\mathrm{r}}$ respectively. Laboratory mutants have been obtained that overproduce PBP5 (Ent. hirae R40) and $\mathrm{PBP}^{\mathrm{r}}$ (Ent. hirae S185r) and, in parallel with this, have a much increased penicillin-resistance $[21,22]$. Experiments were undertaken with the aim of unravelling the primary structure of the Ent. hirae R40 PBP5.

\section{MATERIALS AND METHODS}

\section{Bacterial strains}

Ent. hirae strains R40 and Rev14 [21,23] were gifts from Dr. R. Fontana and Dr. P. Canepari (University of Verona, Verona, Italy). MAX Efficiency Esch. coli $\mathrm{DH} 5 \alpha \mathrm{F}^{\prime} \mathrm{IQ}$ competent strain was from Bethesda Research Laboratories (Gaithersburg MD, U.S.A.). Esch. coli HB101 and JM105 were also used.

\section{Membranes}

Ent. hirae cells were grown unshaken at $37^{\circ} \mathrm{C}$ in $500 \mathrm{ml}$ of SB medium [24] and collected at the late exponential phase $\left(A_{550}=6.0\right)$. The membranes were prepared as described previously $[22,24,25]$. The proteins were measured by the Lowry method as modified by Coyette et al. [26].

\section{Labelling with benzyl $\left[{ }^{14}\right.$ Clpenicillin, SDS/PAGE and fluorography}

Samples were labelled with benzyl $\left[{ }^{14} \mathrm{C}\right]$ penicillin $(54 \mathrm{Ci} / \mathrm{mol}$; Amersham International, Amersham, Bucks., U.K.) and submitted to SDS/PAGE. Fluorography of the gels and estimation of the PBPs by densitometry of the fluorograms were performed as described previously [22,25]. Mean values (ten assays) of the molecular masses of the PBPs were determined by using BSA (66.3 kDa), ovalbumin (42.7 kDa), Streptomyces R61 DD-

\footnotetext{
Abbreviation used: PBP, penicillin-binding protein.

$\ddagger$ To whom correspondence should be addressed.

The nucleotide sequence data reported will appear in the EMBL, GenBank and DDBJ Nucleotide Sequence Databases under the accession number X62280.
} 
carboxypeptidase (38 kDa), carbonic anhydrase (29 kDa), myoglobin $\mathrm{CNBr}$-cleavage products $(17.2,14.6,8.24,6.4$ and $2.6 \mathrm{kDa})$ and hen egg-white lysozyme $(14 \mathrm{kDa})$ as standards. The values of the second-order rate constant of protein acylation and first-order rate of protein deacylation were measured, and the antibiotic concentrations and incubation times necessary to achieve a given extent of saturation of the PBPs were calculated as described previously $[27,28]$.

\section{Purification of the PBP5 tryptic-digest derivatives and amino acid microsequencing}

The PBP5 tryptic-digest derivatives, referred to as t-PBP5s, were purified essentially as described by Piras et al. [22] but with the following modifications. (1) The Q-Sepharose column was equilibrated and eluted with $25 \mathrm{~mm}$-Tris/borate buffer, $\mathrm{pH} 8.0$. (2) Fractions from the first chromatography were concentrated to $15 \mathrm{ml}$, dialysed, divided into $5 \mathrm{ml}$ samples and filtered on a $1 \mathrm{ml}$ MonoQ HR 5/5 column equilibrated with $20 \mathrm{~mm}$-Bistris/

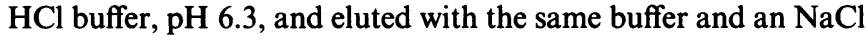
gradient $(0-1 \mathrm{M})$. (3) Fractions from step (2) were concentrated to $2 \mathrm{ml}$ by ultrafiltration, adjusted to $0.85 \mathrm{M}-\left(\mathrm{NH}_{4}\right)_{2} \mathrm{SO}_{4}$ in $50 \mathrm{~mm}$ -

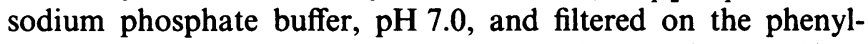
Superose column used previously [22]. Each step of the purification procedure was monitored by SDS/PAGE of samples previously labelled with benzyl $\left[{ }^{14} \mathrm{C}\right]$ penicillin. Electroblotted peptides were microsequenced as described by Piras et al. [22].

\section{Antibodies and immunoassays}

Adult rabbits were injected subcutaneously with a preparation emulsified in complete Freund's adjuvant and containing $80 \mu \mathrm{g}$ (total amount) of several peptide fragments of PBP5 purified from Ent. hirae R40 [29]. The same injection was repeated four times at 15-day intervals. A final injection was made with a preparation containing $140 \mu \mathrm{g}$ of $67 \mathrm{kDa}$ and $63 \mathrm{kDa}$ peptide fragments ([29] and the Results section) in a ratio of $4: 1$. Elimination of non-specific antibodies was made by immunoadsorption of the antiserum by using a mixture of Esch. coli HB101 and Ent. hirae Rev14 cell lysates as described below. (Note that strain Rev14 lacks PBP5.)

Late-exponential-phase cells of Esch. coli and Ent. hirae Rev14 were collected separately from 1-litre cultures and resuspended separately in $50 \mathrm{ml}$ of lysozyme solution $(1 \mathrm{mg} / \mathrm{ml})$. The Esch. coli cell suspension was supplemented with $5 \mathrm{~mm}$ EDTA and kept on ice for $30 \mathrm{~min}$. The Rev14 cell suspension was incubated at $37^{\circ} \mathrm{C}$ for $30 \mathrm{~min}$. The two cell lysates were mixed and the final $100 \mathrm{ml}$ preparation was (i) boiled for $15 \mathrm{~min}$ in a microwave oven, (ii) cooled and treated for $30 \mathrm{~min}$ at $37^{\circ} \mathrm{C}$ with $2 \mathrm{mg}$ of DNAase and $2 \mathrm{mg}$ of RNAase, (iii) boiled for $5 \mathrm{~min}$ as above, (iv) cooled and shaken for $90 \mathrm{~min}$ at $22^{\circ} \mathrm{C}$ in the presence of a $30 \mathrm{~cm} \times 30 \mathrm{~cm}$ nitrocellulose sheet cut into small pieces, (v) supplemented with $1.5 \mathrm{~g}$ of BSA, $1.5 \mathrm{ml}$ of $1 \%(\mathrm{w} / \mathrm{v})$ $\mathrm{NaN}_{3}, 30 \mathrm{ml}$ of water and $15 \mathrm{ml}$ of $10 \times$ TBS $(5 \mathrm{M}-\mathrm{Nacl} / 200 \mathrm{~mm}-$ Tris/ $\mathrm{HCl}$ buffer, $\mathrm{pH} 7.5$ ), and (vi) incubated at $22^{\circ} \mathrm{C}$ for $30 \mathrm{~min}$. The antiserum was diluted 100 -fold in the mixture and shaken for $16 \mathrm{~h}$ at $22^{\circ} \mathrm{C}$. After centrifugation $(40000 \mathrm{~g}$ for $20 \mathrm{~min})$, the purified antiserum was diluted 50-fold with TTBS [TBS containing $0.05 \%(v / v)$ Tween 20 and $1 \%(w / v)$ BSA] before use. Immunodetection was performed on proteins or peptides transferred from polyacrylamide slab gels on to $0.45 \mu \mathrm{m}$-pore-size Millipore HA type nitrocellulose sheets as described by Piras et al. [22].

\section{DNA recombinant techniques and nucleotide sequencing}

Restriction endonucleases, T7 DNA polymerase, calf intestinal alkaline phosphatase and T4 DNA ligase were from Boehringer (Mannheim, Germany) and Bethesda Research Laboratories
(Gaithersburg, MD, U.S.A.). $\left[\gamma^{32}\right.$ P $]$ dATP and $\left[\alpha-\left[{ }^{35}\right.\right.$ S $]$ thio $]$ ATP were from Amersham International and ampicillin was from Beecham (Brussels, Belgium). Oligonucleotides were synthesized by Eurogentec (Liège, Belgium). The Ent. hirae R40 chromosomal DNA was prepared as described previously [30]. This procedure includes treatments with lysozyme in the presence of sucrose, SDS and proteinase K. Preparation of plasmid DNA, transformation of Esch. coli, digestion of DNA with restriction enzymes, treatment with calf intestinal alkaline phosphatase, ligation and agarose-gel electrophoresis of plasmids and digested DNAs were performed essentially as described by Sambrook et al. [31]. DNA fragments were purified by using the Geneclean procedure (Bio-101, La Jolla, CA, U.S.A.), subcloned into bacteriophages M13mp18 and M13mp19 and sequenced with the Sequenase kit (U.S. Biochemical Corp., Cleveland, OH, U.S.A.) by using the dideoxynucleotide chain-termination method [32].

\section{Amplification by PCR}

PCR amplification was performed as described by Piras et al. [22] except that before the first cycle the DNA template was treated at $94^{\circ} \mathrm{C}$ for $5 \mathrm{~min}$ and after the 30th cycle the time at $72^{\circ} \mathrm{C}$ was $7 \mathrm{~min}$. The PCR reaction product (i.e. a 476 bp DNA segment) was (i) submitted to PAGE (6\% acrylamide) in nondenaturing TBE buffer (1 mM-EDTA/40 mM-Tris/borate buffer, pH 8 in a Bio-Rad Mini Protean apparatus, (ii) electroeluted from the gel in $10 \mathrm{~mm}$-Tris/ $\mathrm{HCl}$ buffer, $\mathrm{pH} 8.0$, containing $5 \mathrm{~mm}$ $\mathrm{NaCl}$ and $1 \mathrm{~mm}$-EDTA, (iii) extracted twice with phenol/ chloroform $(1: 1, \mathrm{v} / \mathrm{v})$ and precipitated with ethanol, (iv) digested with BamHI and EcoRI restriction enzymes (Bethesda Research Laboratories), and (v) cloned in bacteriophages M13mp18 and M13mp19 [31]. MAX Efficiency Esch. coli

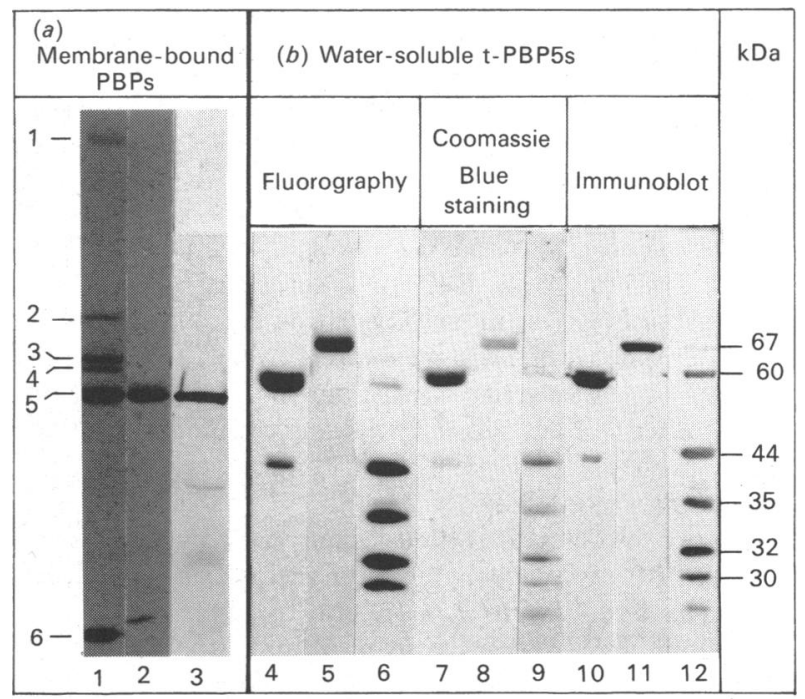

Fig. 1. SDS/PAGE of the Ent. hirae R40 membrane-bound PBPs (a) and the water-soluble PBP5 tryptic-digest peptides (b)

Conditions of electrophoresis : (a) $7.2 \%(w / v)$ acrylamide; $16 \mathrm{~h}$; gel length $32 \mathrm{~cm} ;(b) 8.5 \%$ (w/v) acrylamide; $5 \mathrm{~h}$; gel length $16 \mathrm{~cm}$. (a) Membranes (200 $\mu \mathrm{g}$ of protein) were labelled with $100 \mu \mathrm{M}$-benzyl$\left[{ }^{14} \mathrm{C}\right]$ penicillin for $60 \mathrm{~min}$ either directly (lane 1) or after previous treatment with $15 \mu \mathrm{M}$ non-radioactive benzylpenicillin for $10 \mathrm{~min}$ (lane 2), and the PBPs were detected by fluorography of the gels. Immunodetection (lane 3) of PBP5 in isolated membranes (100 $\mu \mathrm{g}$ of total protein) with the anti-PBP5 serum was also performed. $(b)$ Isolation of the $60 \mathrm{kDa}$ t-PBP5 (lanes 4,7 and 10 ), the $67 \mathrm{kDa} \mathrm{t}$ PBP5 (lanes 5, 8 and 11) and tryptic digestion of the purified $67 \mathrm{kDa}$ t-PBP5 (lanes 6, 9 and 12). The peptides seen by fluorography in lanes $4-6(5 \mu \mathrm{g}, 2 \mu \mathrm{g}$ and $10 \mu \mathrm{g}$ respectively) were labelled with $100 \mu \mathrm{M}$-benzyl $\left[{ }^{14} \mathrm{C}\right]$ penicillin for $60 \mathrm{~min}$ after proteolysis. 
DH $5 \alpha \mathrm{F}^{\prime} \mathrm{IQ}$ competent cells were used for the transformation experiments.

\section{RESULTS}

\section{Specific labelling of PBP5 in Ent. hirae R40 membranes with} benzyl[ ${ }^{14} \mathrm{C}$ |penicillin

Ent. hirae R40 contains the six species-specific membranebound PBPs [33]: PBP1 (119 $\pm 8 \mathrm{kDa})$, PBP2 $(84 \pm 1.7 \mathrm{kDa})$, PBP3 (77 $\pm 0.6 \mathrm{kDa})$, PBP4 (75 $\pm 0.7 \mathrm{kDa})$, PBP5 $(71 \pm 0.7 \mathrm{kDa})$ and PBP6 (43 $\pm 1 \mathrm{kDa})$ (Fig. 1, lane 1). When compared with Ent. hirae A.T.C.C. 9790, the peculiarity of Ent. hirae R40 is that

(1) 67 kDa t-PBP5: TISEKEALEKYQNIYGAVAIKGLEISN...

(2) 60 kDa t-PBP5: INKQPNLIFPQMEDTDKVSLTSEEAKXGDILDRNGKKLA...

(3) 44 kDa t-PBP5: NAELSXNGKIGRSGLETTYDKELRGTWGGKLSITDADG...

(4) 32 kDa t-PBP5: MTGISQEDYQAYTENKDQPFI...

(5) 30 kDa t-PBP5: DQPFISRFATGYAXGSTFKMITAAIGLDNQTLNP...

Fig. 2. N-Terminal amino acid sequences of the PBP5 tryptic-digest fragments

The underlined sequences were those on the basis of which the two oligonucleotides shown in Fig. 3 were synthesized. Note the overlap DQPFI between the $32 \mathrm{kDa}$ t-PBP5 and the $30 \mathrm{kDa} t-P B P 5$. the $71 \mathrm{kDa}$ PBP5 of low penicillin affinity represents about onehalf of all the PBPs present. In order to map out fragments specifically produced by tryptic digestion of PBP5, membranes of Ent. hirae R40 were prepared in which PBP5 was virtually the only PBP to be labelled with benzyl $\left[{ }^{14} \mathrm{C}\right]$ penicillin (Fig. 1, lane 2). For this purpose membranes were treated first with $15 \mu \mathrm{M}$ nonradioactive benzylpenicillin for $10 \mathrm{~min}$ at $37^{\circ} \mathrm{C}$ (under which conditions PBPs 1, 2, 3 and 4 were fully saturated, PBP6 was saturated by $90 \%$ and PBP5 remained in a free form), and then with $100 \mu \mathrm{M}$-benzyl $\left[{ }^{14} \mathrm{C}\right]$ penicillin for $60 \mathrm{~min}$ at $37^{\circ} \mathrm{C}$, thus achieving complete labelling of PBP5.

Tryptic digestion of the Ent. hirae R40 membranes: the $67 \mathrm{kDa}$ t-PBP5 and $60 \mathrm{kDa}$ t-PBP5 tryptic-digest fragments

It was known that PBP5 could be quantitatively converted into water-soluble penicillin-binding derivatives by trypsin treatment of isolated membranes of Ent. hirae R40 [29,34]. On the basis of these data, a membrane suspension [ $1.5 \mathrm{~g}$ of total protein in $120 \mathrm{ml}$ of $40 \mathrm{~mm}$-sodium phosphate buffer, $\mathrm{pH} \mathrm{6.5,} \mathrm{containing}$ $1 \mathrm{~mm}-\mathrm{MgCl}_{2}$ and $3 \%(\mathrm{v} / \mathrm{v})$ glycerol] was incubated with $0.5 \%$ (w/w) trypsin (type XI; Sigma Chemical Co.) for $15 \mathrm{~min}$ at $37^{\circ} \mathrm{C}$. The reaction was stopped by addition of $10 \mathrm{mg}$ of soyabean trypsin inhibitor, and the preparation was submitted to ultracentrifugation at $105000 \mathrm{~g}$ for $1 \mathrm{~h}$.

Analysis of the supernatant showed that, as a result of this relatively mild proteolytic treatment, $85 \%$ of the membranebound PBP5 (initial amount $120 \mathrm{nmol}$ or $8.3 \mathrm{mg}$ ) was converted into four water-soluble fragments, of $67 \pm 0.6 \mathrm{kDa}(55 \%)$,

\section{Oligonucleotide 1}



Oligonucleotide 2

Fig. 3. Oligonucleotides used as primers for PCR amplification, PCR product and amino acid sequence of PBP5-PCR

The probe used to screen the clones and the Pst I cleavage site are underlined. 
$63 \pm 0.7 \mathrm{kDa}(14 \%), 60 \pm 1.4 \mathrm{kDa}(7 \%)$ and $44 \pm 1.2 \mathrm{kDa}(9 \%)$. The fragments bound benzyl $\left[{ }^{14} \mathrm{C}\right]$ penicillin with a low affinity comparable with that of the membrane-bound PBP5 (see below). They had apparent molecular masses comparable with those of the radioactive fragments obtained from membranes whose PBP5 had been selectively labelled with benzyl $\left[{ }^{14} \mathrm{C}\right]$ penicillin before trypsin treatment.

The $67 \mathrm{kDa}$ t-PBP5 tryptic-digest fragment was isolated and the $60 \mathrm{kDa}$ t-PBP5 fragment was partially purified (see the Materials and methods section). (1) The supernatant fraction $(120 \mathrm{ml} ; 860 \mathrm{mg}$ of protein) was filtered on the Q-Sepharose FF column and the four aforementioned tryptic-digest fragments were eluted at $0.19-0.24 \mathrm{M}-\mathrm{NaCl}$, with a 20 -fold specific enrichment. (2) The pooled fractions (treated as described in the Materials and methods section) were filtered on the $1 \mathrm{ml}$ MonoQ $\mathrm{HR} 5 / 5$ column. Elution with the $\mathrm{NaCl}$ gradient yielded two fractions. Fraction A, which was eluted at $0.21-0.24 \mathrm{M}-\mathrm{NaCl}$, was considerably enriched in the $67 \mathrm{kDa}$ t-PBP5. Fraction B, which was eluted at $0.19-0.21 \mathrm{M}-\mathrm{NaCl}$, contained almost equivalent amounts of $67 \mathrm{kDa}$ t-PBP5 and $60 \mathrm{kDa}$ t-PBP5 plus much smaller amounts of $44 \mathrm{kDa}$ t-PBP5. (3) Fraction A and fraction $B$ (treated as described in the Materials and methods section) were loaded on to the phenyl-Superose HR5/5 column. The $60 \mathrm{kDa}$ t-PBP5 from fraction $\mathrm{B}$ was eluted at $0.3-0.15 \mathrm{M}$ $\left(\mathrm{NH}_{4}\right)_{2} \mathrm{SO}_{4}$. It was about $85 \%$ pure (Fig. 1, lanes 4 and 7). The $67 \mathrm{kDa}$ t-PBP5 from fraction $\mathrm{A}$ was eluted at an $\left(\mathrm{NH}_{4}\right)_{2} \mathrm{SO}_{4}$ concentration of less than $0.15 \mathrm{M}$. It was at least $95 \%$ pure (Fig. 1 , lanes 5 and 8).

Tryptic digestion of the purified $67 \mathrm{kDa}$ t-PBP5: the $44 \mathrm{kDa}$ t-PBP5, 35 kDa t-PBP5, 32 kDa PBP5 and 30 kDa t-PBP5 tryptic-digest fragments

The $67 \mathrm{kDa}$ t-PBP5 $(0.4 \mathrm{mg}$ in $0.4 \mathrm{ml}$ of $40 \mathrm{~mm}$-sodium phosphate buffer, $\mathrm{pH} 6.5$, containing $1 \mathrm{~mm}-\mathrm{MgCl}_{2}$ ) was incubated with $10 \%(\mathrm{w} / \mathrm{w})$ trypsin for $60 \mathrm{~min}$ at $37^{\circ} \mathrm{C}$. As a result of this drastic proteolytic treatment, the $67 \mathrm{kDa}$ t-PBP5 was degraded into six fragments (Fig. 1, lane 9). Fragments of molecular mass smaller than $30 \mathrm{kDa}$ lacked penicillin-binding capacity (Fig. 1, lanes 6 and 9). With the procedure described previously $[27,28]$, the membrane-bound PBP5 and the $67 \mathrm{kDa}, 60 \mathrm{kDa}$ and $44 \mathrm{kDa}$ fragments reacted with benzylpenicillin with the same low secondorder rate constant of protein acylation $\left(5-9 \mathrm{M}^{-1} \cdot \mathrm{s}^{-1}\right)$ and the same low first-order rate constant of protein deacylation $\left(6 \times 10^{-6}-13 \times 10^{-6} \mathrm{~s}^{-1}\right)$. Note that, at those concentrations needed to saturate PBP5, penicillin partially acylated BSA.

\section{Specificity profile of the anti-(67 kDa t-PBP5) antibodies}

Antibodies raised against the tryptic derivatives of PBP5 (see the Materials and methods section) reacted only with PBP5 (plus two weaker bands) but not with the other PBPs present in the membranes of Ent. hirae R40 (Fig. 1, lane 3). They also reacted with all the tryptic-digest PBP5 fragments described above (Fig. 1, lanes 10-12).

\section{Amino acid sequencing data and PCR amplification}

The peptide fragments (usually $600 \mathrm{pmol}$ ) separated by SDS/ PAGE as shown in Fig. 1 (lanes 4-to 12) were electroblotted and the amino acid sequence of the $N$-terminal region of each individual peptide was determined by automated microsequence analysis (Fig. 2). On the basis of these data, the two oligonucleotides shown in Fig. 3 were synthesized. Oligonucleotide 1 had a BamHI site at the 5 '-end and coded for the sequence Q11-K 17 of the $60 \mathrm{kDa}$ t-PBP5. Oligonucleotide 2 had an EcoRI site at the 5 '-end and was complementary to the nucleotide sequence coding for the sequence E16-L23 of the $44 \mathrm{kDa}$ t-PBP5. Amplification by the PCR technique with the oligo-

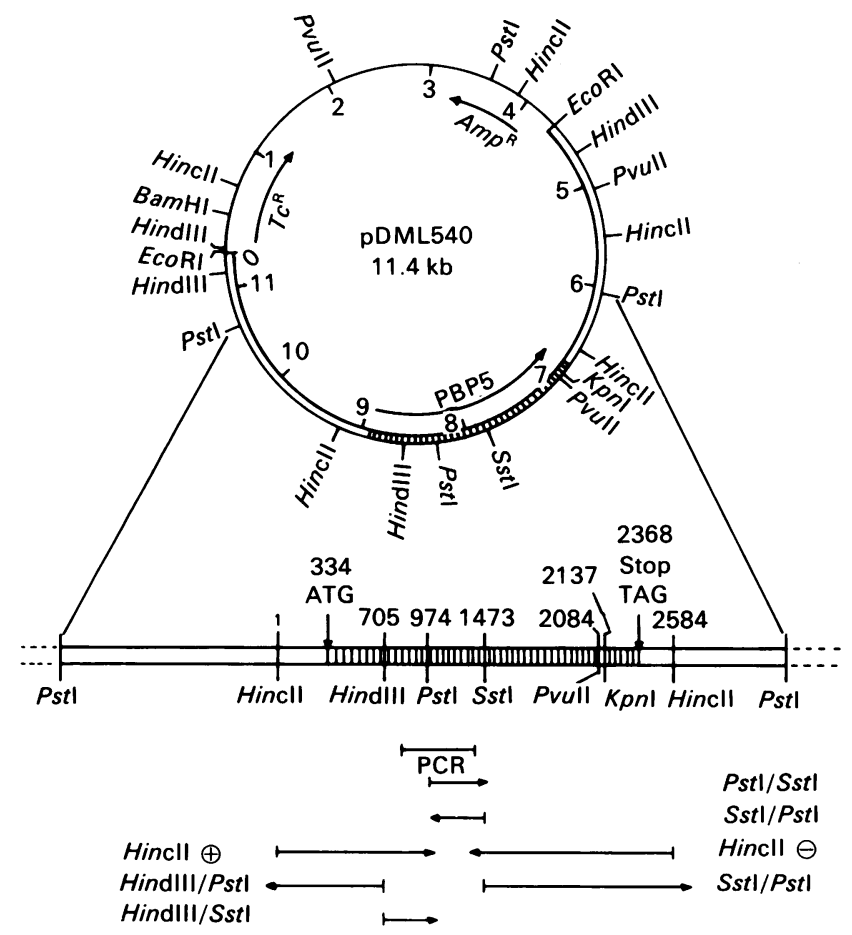

Fig. 4. Restriction map of pDML540 and strategy used for nucleotide sequencing of the Ent. hirae R40 PBP5-encoding gene

nucleotides as primers and the Ent. hirae R40 DNA as template generated a 476 bp DNA segment the sequence of which translated into a 155-amino acid-residue segment. This peptide, called PBP5-PCR, is also shown in Fig. 3.

\section{Gene cloning and sequencing}

The Ent. hirae R40 DNA $(2 \mu \mathrm{g})$ was partially digested with EcoRI, the DNA fragments were inserted into pBR322 $(1 \mu \mathrm{g})$ previously cut by EcoRI and dephosphorylated, and the ligation mixture $(5 \mu \mathrm{l}$ out of $20 \mu \mathrm{l})$ served to transform Esh. coli HB101 cells. Transformants were selected on solid LB medium containing $50 \mu \mathrm{g}$ of ampicillin $/ \mathrm{ml}$, transferred on to nylon filters (Amersham International) and screened with the $\left[\gamma^{32} \mathrm{P}\right]$ ATPlabelled 24-mer probe (Fig. 3). Hybridization was carried out at $50^{\circ} \mathrm{C}$ and post-hybridization washing at $65^{\circ} \mathrm{C}\left(T_{\mathrm{m}} 72^{\circ} \mathrm{C}\right)$. Of the 2150 ampicillin-resistant Esch. coli transformants tested, one clone gave a strong positive reaction with the probe. The harboured plasmid pDML540 $(11.4 \mathrm{~kb})$ had acquired a $7.1 \mathrm{~kb}$ insert. pDML540, whose restriction map is shown in Fig. 4, was digested separately by HincII and by PstI and SstI. The HincII $2.6 \mathrm{~kb}$ DNA fragment and the PstI-SstI $0.5 \mathrm{~kb}$ DNA fragment hybridized with the probe (results not shown). Nucleotide sequencing of the PstI-SstI fragment allowed, on the basis of the position of the PstI site in the PBP5-PCR product, establishment of the orientation of the PBP5-encoding gene, from PstI to Sst I. The HincII $2.6 \mathrm{~kb}$ DNA fragment was sequenced on both strands, by use of the strategy also shown in Fig. 4. A 2034-nucleotideresidue open reading frame (Fig. 5) started at position 334 with an ATG codon and terminated at position 2368 with a TAG stop codon.

\section{Amino acid sequence of PBP5 and sequence-similarity searches}

The open reading frame translated into a 678-amino acidresidue protein. As derived from the amino acid sequence (Fig. 5), the $67 \mathrm{kDa}, 60 \mathrm{kDa}, 44 \mathrm{kDa}, 32 \mathrm{kDa}$ and $30 \mathrm{kDa}$ peptide fragments were produced by tryptic cleavage of the bonds K $76-\mathrm{T}$, 
Hincll

GTCAACTCITGGGAAGTATTAAAACCAATTTACCTGAAAGTGTATTAATTGATTGTGGCATTGATTTCTTAAAAGATGACAAACCAATTGATACGTTATCTGTACCAGTTGAAGGTAGTT 1 121 $\begin{array}{llllllllllll}(-35) & (-10) & R B S & K & D & N & R & R & \end{array}$ TTAGAAACAAGCGATTGTCGTTGTTTTTAGCTTCTTTTCTTATGGTAAAATGGATAGAAGTTAAGATAAGAAAATGTGAGCGGAGGGACAAAATGAAACGAAGTGACAATCATCGTAGG

241

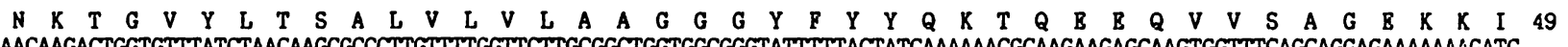
AACAAGACTGGTGTTATCTAACAAGCGCCTTTTTTTGGTTCTTGCGGCTGGTGGCGGGTATTTTTACTATCAAAAAACGCAAGAAGAGCAAGTGGTTTCAGCAGGAGAAAAAAAGATC 361

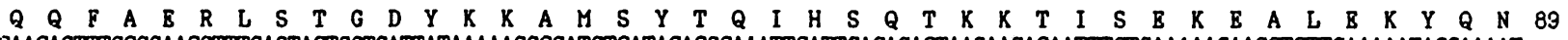
CAACAGTTTGCGAACGTTTGAGTACTGGTGATTATAAAAAGGCGATGTCATACACGCAAATTCATTCACAGACTAAGAAGACAATTTCTGAAAAAGAGCTCTTGAAAATACCAAAAT 481

600

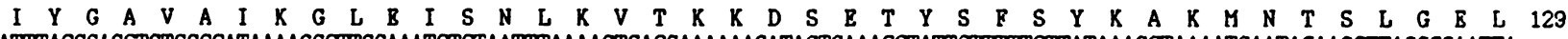
ATTTACGGAGCTGTGGCCATAAAAGGCTTGGAAATCTCTAATTTAAAAGTGACGAAAAAAGATAGTGAAACCTATTCITTITCTTATAAAGCTAAAATGAATACAAGCTTAGGCGAATTA 601

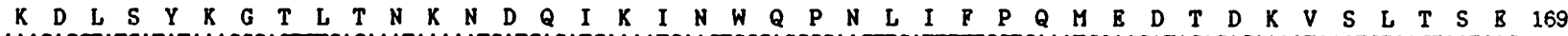
AAAGACCTATCATATAAAGGACTTTGACAAATAAA_AATGATCAGATCAAAATCAACTGGCAGCCGAACTTGATTTTCCTCAAATGGAAGATACAGACAAAGTAAGTCTGACTAGTGAG
721

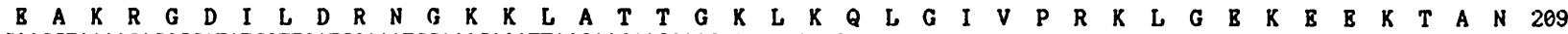
GAAGCTAAAAGAGCGATATCCTTGATCGAAATGGAAAGAAATTAGCAACGACGGGCAAATTGAAACAGTTAGGGATCGTTCCTAGAAAGCTGGGAGAAAAAGAAGAGAAACAGCAAAC

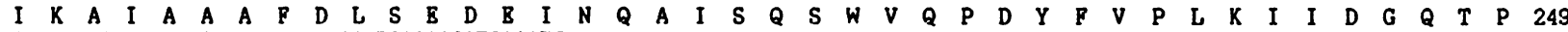
ATCAAAGCAATTGCTGCAGCTTTTGATCTTTCAGAAGATGAAATCAATCAAGCTATCTCTCAAAGTTGGGTACAACCGGACTACTITGTTCCTCTAAAAATCATTGATGGACAAACCCCC
P61

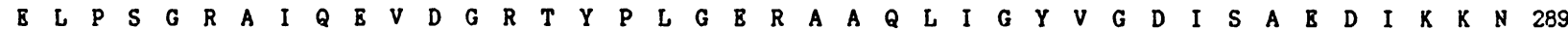
GAATTGCCAAGCGGACGAGCGATCCAAGAAGTTGATGGTCGCACCTATCCGTTAGGCGAACGAGCAGCGCAATTGATTGGTTATGTTGGTGATATCTCAGCAGAAGATATCAAAAAGAAT 1081

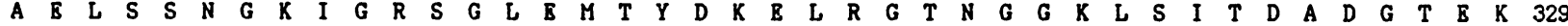
GCTGAATTAAGTAGTAATGGTAAAATTGGTCGTTCTGGTCTGGAAATGACTTATGACAAAGAACTACGTGGCACCAATGGAGGGAAATTGAGTATTACGGATGCTGATGGGACAGAAAAA 1201 1320

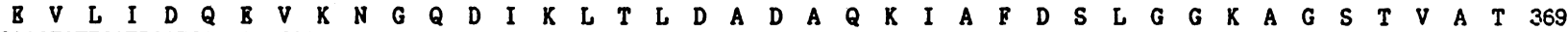
GAAGTATTGATTGATCAAGAAGTGAAAAATGGTCAGGATATCAAATTAACTCTTGATGCCGATGCTCAAAAAATCGCATTTGATAGTTTAGGTGGAAAAGCGGGTTCAACAGTAGCGACT 1321 1440

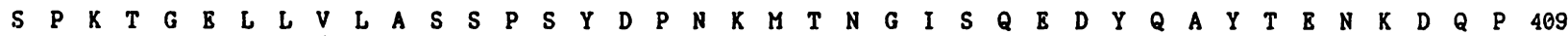
TCGCCAAAAACGGGTGAGTTGTTAGTATTAGCGAGCTCTCCAAGTTATGATCCAAACAAAATGACAAATGGAATCTCTCAAGAAGATTATCAAGCCTATACGGAAAATAAAGATCAACCA

$1441 \quad$ Sst 1560

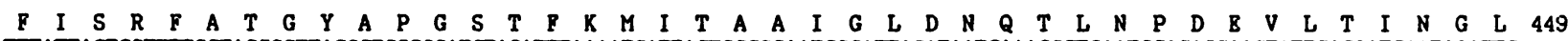
TTTATTAGTCGTTTGCTACCGGTTACGCTCCCGGATCTACATTTAAAATGATTACTGCCGCAATCGGATTAGATAATCAAACGCTGAATCCAGACGAAGTATTGACGATCAATGGATTG 1561

1680


AAATGGCAAAAAGCCAATCATGGGGATCGTATCAAGTTACTCGTGTCAGCGATGTGCCTCAAGTCAATCTGAGAAACCCAATGATTTATTCAGATAATATCTATATGGCTCAAGAAACC 1681

1800

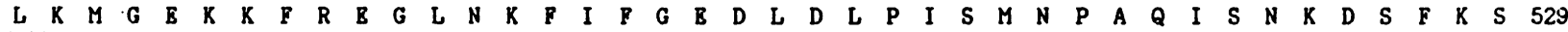
TTTAAAATGGGTGAGAAGAATTCCGCGAAGGATTAAATAAATTCATTITTGGGAAGACTTAGATTTGCCGATCAGCATGAATCCCGCACAAATCTCAAATAAGGATAGTTTCAAGTCA 1801

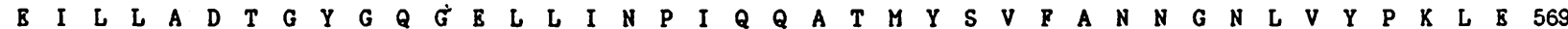
GAAATCTIATTAGCAGATACTGGTTATGGGCAGGGAGACTATTGATCAATCCGATCCAACAAGCAACGATGTATTCTGTTTTGCTAATAATGGAAATCTCGTTATCCAAATTAGAG 1921

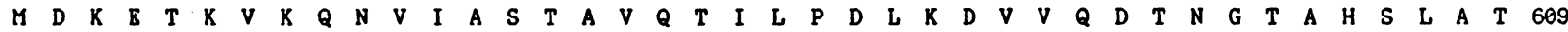
ATGGATAAAGAAACGAAAGTAAACAAAATGTCATTGCTTCAACAGCTGTACAGACGATTCTGCCAGATTTGAAAGATGTTGTCAAGATACGAATGGTACCGCTCATTCTTTAGCTALT
2041
PVull

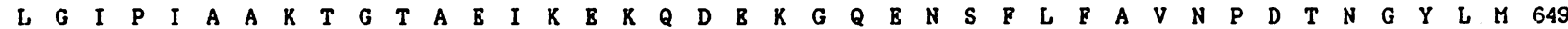
TTAGGCATACCAATAGCAGCAAAAACTGGTACAGCGGAAATCAAAGAAAACAAGATGAAAAAGGACAAGAAAATAGCTTCCTATTTGCTGTGAATCCTGATACAAATGGTTATCTCATG 2160

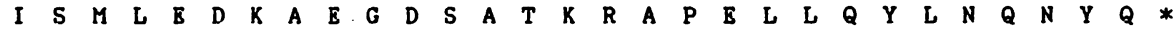

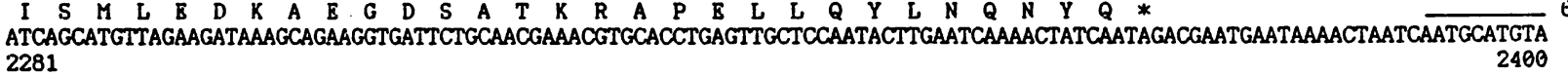

GTCACTACTTACATTTGGGTAGGAAAGTAAATTATTTAGAATACTACAGTCACTCGATTAGTTTTTTTATATAGGGATGCTTTAGAATGATCITITTACCTTTGGTTTAACGATAAAA 2401

GTAGCTAAACCTAATAAAATGAATCCAATAATGAATGGCATCGTATGATGGAAATTAGCATATGTTGAC

$25212580 \frac{21 \mathrm{HinCll}}{2}$

Fig. 5. Nucleotide sequence of the Ent. hirae R40 PBP5-encoding gene and deduced amino acid sequence of the protein

The potential promoter $-35,-10$ hexamers, the Shine-Dalgarno sequence (RBS), the restriction sites and the probe used to screen the clones are underlined. The inverted repeats of the putative transcription termination signal are indicated by horizontal arrows.

Vol. 280 


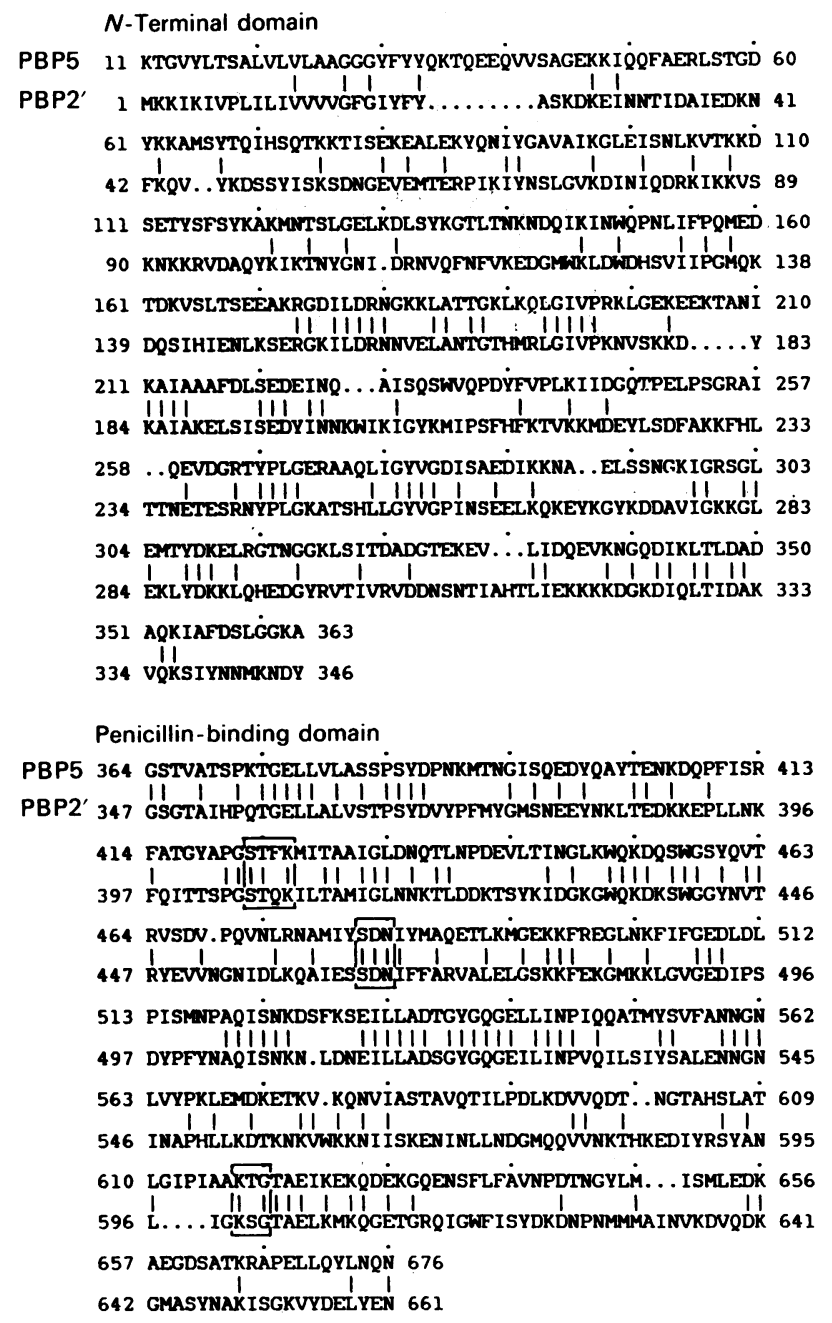

Fig. 6. Amino acid sequence alignment of the Ent. hirae R40 PBP5 and Staph. aureus PBP2'

Vertical lines indicate strict identities. The S*XXK, SDN and KT(S)G motifs the penicillin-binding domains are boxed.

K146-I, K288-N, K389-M and K406-D respectively. The Ent. hirae R40 PBP5 had significant similarity in the primary structure to the Esch. coli PBPs 2 [35] and 3 [36] (27\% and 22\% strict identities respectively), the Strep. pneumoniae PBPs $2 X$ [16] and 2B [37] (24\% and $25 \%$ respectively), the $N$. gonorrhoeae PBP2 [18] $(25 \%)$ and the methicillin-resistant Staph. aureus PBP2' [12] (33\%). Alignment of the Ent. hirae PBP5 and the Staph. aureus PBP2', by using the Bestfit program in the GCG package (gap weight: 5.0 ; length weight: 0.3 ), generated 223 strict identities (Fig. 6). The significance of the degree of similarity found between the two aligned amino acid sequences was estimated with the seqdp program of Goad \& Kanehisa [38]. The alignment had scores of -400 for the $N$-terminal domains $(27 \%$ strict identities) and -490 for the $C$-terminal domain ( $40 \%$ strict identities). These scores were 30 and 53 standard deviations respectively above that expected from a run of 20 randomized pairs of proteins having the same amino acid compositions as the two domains under consideration.

\section{DISCUSSION}

Upstream from the ATG initiation codon of the Ent. hirae R40 PBP5-encoding gene there occur nucleotide sequences that are analogous to the canonical -35 and -10 promoter sequences found in Esch. coli [39], lactococci [40] and pneumococci [41]. Of the two potential -35 hexamers, that starting at position T261 fits best the known rules for an active promoter sequence. The GGAGG pentamer located 11 nucleotide residues upstream from the ATG codon has the characteristics of the ShineDalgarno sequences found in Staph. aureus and Bacillus species [42]. The TAG stop codon is followed by an inverted repeat, which might act as a terminator.

The $\beta$-lactamases of class A and the Streptomyces R61 lowmolecular-mass PBP of known three-dimensional structure have a unique signature in the form of four conserved amino acid groupings, which, as a result of the folding of the polypeptide chain, are brought close to each other and define the enzyme active site. The $S^{*}$ XXK motif, about 60 residues downstream from the $N$-terminus of the protein, is central to the cavity with the active-site serine $S^{*}$ located at the $N$-terminus of one $a$-helix. The S(Y)XN motif on a loop that connects two $\alpha$-helices forms one side of the cavity. The triad $\mathrm{K}(\mathrm{H}) \mathrm{T}(\mathrm{S}) \mathrm{G}$, about 60 residues upstream from the $C$-terminus of the protein, occurs on the innermost strand of a five-stranded $\beta$-sheet and forms the other side of the cavity. Finally, a peptide segment, the D/E motif, containing two dicarboxylic amino acid residues occurs, in the primary structure, downstream of the $\mathrm{S}(\mathrm{Y}) \mathrm{XN}$ motif and, in the tertiary structure, on a loop or small $\alpha$-helix at the entry of the cavity $[1,43]$.

Assuming that this model applies to the high-molecular-mass PBPs, the methicillin-resistant Staph. aureus 670-amino acidresidue PBP2' [12] consists of a $\sim 345$-amino acid-residue $N$ terminal domain connected to a $\sim 325$-amino acid-residue $C$ terminal penicillin-binding domain and has the active-site serine residue at position 405 (Fig. 6). Similarly, the penicillin-resistant Ent. hirae R40 678-amino acid-residue PBP5 consists of a $\sim 360$ amino acid-residue $N$-terminal domain connected to a $\sim 320$ amino acid-residue penicillin-binding domain and has the activesite serine residue at position 422 . Amino acid alignment and sequence-similarity searches reveal that the $N$-terminal domains and the $C$-terminal domains of PBP2' and PBP5 are very similar. Alignment also highlights the occurrence of the conserved S*XXK, SDN and KT(S)G motifs. E508 or E542 (in the numbering of PBP5) are possible candidates for the E/D motif.

It has been proposed that the methicillin-resistant Staph. aureus strains have imported an inducible high-molecular-mass PBP2' and that the encoding gene has probably evolved by recombination of a PBP gene of some bacterium and an inducible $\beta$-lactamase gene [12]. In contrast, the enterococcal PBP5 gene seems to be constitutive. Whatever their origin, the Staph. aureus PBP2' and Ent. hirae PBP5 are only about 25 times more susceptible to penicillin than BSA. Each of these PBPs can take over the functions needed for wall peptidoglycan assembly under conditions where all the other PBPs are inactivated by reaction with $\beta$-lactam antibiotics. These high-molecular-mass PBPs probably represent the ultimate achievement in intrinsic resistance to these antibiotics.

Tryptic cleavage of the K76-T77 bond causes release of PBP5 from the Ent. hirae R40 membranes in the form of a pencillinbinding water-soluble derivative, showing that the membrane anchor of the PBP is located upstream from K76. Comparison of the molecular mass of the membrane-bound PBP (71000 Da, as derived from migration on SDS/PAGE) with that of the precursor $(74862 \mathrm{Da})$, suggests that the precursor may undergo processing by elimination of a 30-40-amino acid-residue peptide at the $N$-terminus of the protein. This region possesses six diamino acids between M1 and T12, a long G13-G29 hydrophobic segment and several putative leader-peptidase-cleavage sites (S18-A19, A25-A26, A26-G27, S43-A44 or A44-A45) [44]. 
The exact mode of membrane anchoring of PBP5 will remain unknown as long as the membrane-bound form has not been isolated and its $N$-terminal region has not been sequenced. Note that immunological and penicillin-binding analyses (results not shown) indicate that PBP5 is expressed in Esch. coli and comigrates with the natural form, thus suggesting that in Ent. hirae R40 PBP5 is probably not processed.

This work was supported in part by the Fonds National de la Recherche Scientifique (to J. C.), the Fonds de la Recherche Scientifique Médicale (Contract $\mathrm{n}^{\circ} 3.4537 .88$ ), the Belgian Government (Convention 86/91-90), the Fonds de Recherche de la Faculté de Médecine ULg, and a tripartite agreement between the Walloon Region, SmithKline Beecham (U.K.) and the University of Liège. P. J. and G. P. were Fellows of the Institut pour l'Encouragement de la Recherche Scientifique dans l'Industrie et l'Agriculture, Brussels. The protein sequence work in Gent was supported by the National Incentive Program on Fundamental Research in Life Sciences initiated by the Belgian Science Policy Programming Department (Contract BIO22). Some of this work is part of a dissertation presented by A. E. K. in partial fulfilment for a Ph.D. degree at the University of Liège, 1991.

\section{REFERENCES}

1. Ghuysen, J.-M. (1991) Annu. Rev. Microbiol. 45, 37-67

2. Spratt, B. G. \& Cromie, K. D. (1988) Rev. Infect. Dis. 10, 699-711

3. Joris, B., Ledent, P., Kobayashi, T., Lampen, J. O. \& Ghuysen, J.-M. (1990) FEMS Microbiol. Lett. 70, 107-114

4. Zhu, Y. F., Curran, I. H. A., Joris, B., Ghuysen, J.-M. \& Lampen, J. O. (1990) J. Bacteriol. 172, 1137-1141

5. Begg, K. J., Spratt, B. G. \& Donachie, W. D. (1986) J. Bacteriol. 167, 1004-1008

6. Ikeda, M., Sato, T., Wachi, M., Jung, H. K., Ishino, F., Kobayashi, Y. \& Matsuhashi, M. (1989) J. Bacteriol. 171, 6375-6378

7. Ishino, F., Park, W., Tomioka, S., Tamaki, S., Takase, I., Kunugita, K., Matsuzawa, H., Asoh, S., Ohta, T., Spratt, B. G. \& Matsuhashi, M. (1986) J. Biol. Chem. 261, 7024-7031

8. Joris, B., Dive, G., Henriques, A., Piggot, P. J. \& Ghuysen, J.-M. (1990) Mol. Microbiol. 4, 513-517

9. Taschner, P. E. M., Huls, P. G., Pas, E. \& Woldringh, C. L. (1988) J. Bacteriol. 170, 1533-1540

10. Reynolds, P. E. (1984) Br. Med. Bull. 40, 3-10

11. Reynolds, P. E. \& Brown, D. F. J. (1985) FEBS Lett. 192, 28-32

12. Song, M. D. Wachi, M., Doi, M., Ishino, F. \& Matsuhashi, M. (1987) FEBS Lett. 221, 167-171

13. Hedge, P. J. \& Spratt, B. G. (1985) Nature (London) 318, 478-480

14. Dowson, C. G., Hutchison, A. \& Spratt, B. G. (1989) Mol. Microbiol. 3, 95-102

15. Dowson, C. G., Hutchison, A., Woodford, N., Johnson, A. P., George, P. C. \& Spratt, B. G. (1990) Proc. Natl. Acad. Sci. U.S.A. 87, 5858-5862

16. Laible, G., Hakenbeck, R., Sicard, M. A., Joris, B. \& Ghuysen, J.-M. (1989) Mol. Microbiol. 3, 1337-1348

17. Dowson, C. G., Jephcott, A. E., Gough, K. R. \& Spratt, B. G. (1989) Mol. Microbiol. 3, 35-41

18. Spratt, B. G. (1988) Nature (London) 332, 173-176
19. Spratt, B. G., Zhang, Q.-Y., Jones, D. M., Hutchison, A., Brannigan, J. A. \& Dowson, C. G. (1989) Proc. Natl. Acad. Sci. U.S.A. 86, 8989-8992

20. Zhang, Q.-Y., Jones, D. M., Saez Nieto, J. A., Perez Trallero, E. \& Spratt, B. G. (1990) Antimicrob. Agents Chemother. 34, 1523-1528

21. Fontana, R. Cerini, R., Longoni, P., Grossato, A. \& Canepari, P. (1983) J. Bacteriol. 155, 1343-1350

22. Piras, G., El Kharroubi, A., Van Beeumen, J., Coeme, E., Coyette, J. \& Ghuysen, J.-M. (1990) J. Bacteriol. 172, 6856-6862

23. Fontana, R., Grossato, A., Rossi, L., Cheng, Y. R. \& Satta, G. (1985) Antimicrob. Agents Chemother. 28, 678-683

24. Coyette, J., Perkins, H. R., Polacheck, I., Shockman, G. D. \& Ghuysen, J.-M. (1974) Eur. J. Biochem. 44, 459-468

25. El Kharroubi, A., Piras, G., Jacques, P., Szabo, I., Van Beeumen, J., Coyette, J. \& Ghuysen, J.-M. (1989) Biochem. J. 262, 457-462

26. Coyette, J., Ghuysen, J.-M. \& Fontana, R. (1978) Eur. J. Biochem. 88, 297-305

27. Ghuysen, J.-M., Frère, J.-M., Leyh-Bouille, M., Nguyen-Distèche, M. \& Coyette, J. (1986) Biochem. J. 235, 159-165

28. Leyh-Bouille, M., Nguyen-Distèche, M., Pirlot, S., Veithen, A., Bourguignon, C. \& Ghuysen, J.-M. (1986) Biochem. J. 235, 177-182

29. Jacques, P., El Kharroubi, A., Joris, B., Thonon, F., Piras, G., Coyette, J. \& Ghuysen, J.-M. (1988) in Antibiotic Inhibition of Bacterial Cell Surface Assembly and Function (Actor, P., DaneoMoore, L., Higgins, M. L., Salton, M. R. J. \& Shockman, G. D., eds.), pp. 377-381, American Society for Microbiology, Washington

30. Loureiro dos Santos, A. L. \& Chopin, A. L. (1987) FEMS Microbiol. Lett. 42, 209-212

31. Sambrook, J., Fritsch, E. F. \& Maniatis, T. (1989) Molecular Cloning: A Laboratory Manual, Cold Spring Harbor Laboratory, Cold Spring Harbor

32. Sanger, F., Nicklen, S. \& Coulson, A. R. (1977) Proc. Natl. Acad. Sci. U.S.A. 74, 5463-5467

33. Coyette, J., Ghuysen, J.-M. \& Fontana, R. (1980) Eur. J. Biochem. 110, 445-456

34. El Kharroubi, A., Jacques, P., Piras, G., Coyette, J. \& Ghuysen, J.-M. (1988) in Antibiotic Inhibition of Bacterial Cell Surface Assembly and Function (Actor, P., Daneo-Moore, L., Higgins, M. L., Salton, M. P. J. \& Shockman, G. D., eds.), pp. 367-376, American Society for Microbiology, Washington

35. Asoh, S., Matsuzawa, H., Ishino, F. \& Strominger, J. L. (1986) Eur. J. Biochem. 160, 231-238

36. Nakamura, M., Maruyama, J. N., Soma, M., Kato, J. I., Suzuki, H. \& Hirota, Y. (1983) Mol. Gen. Genet. 191, 1-9

37. Dowson, C. G., Hutchison, A. \& Spratt, B. G. (1989) Nucleic Acids Res. 17, 7518

38. Goad, W. B. \& Kanehisa, M. I. (1982) Nucleic Acids Res. 10, 247-263

39. Hawley, D. K. \& McClure, W. R. (1983) Nucleic Acids Res. 11, 2237-2255

40. De Vos, M. W. (1987) FEMS Microbiol. Rev. 46, 281-295

41. Morrisson, D. A. and Jaurin, B. (1990) Mol. Microbiol. 4, 1143-1152

42. McLaughlin, J. R., Murray, C. L. \& Rabinowitz, J. C. (1981) J. Biol. Chem. 256, 11283-11291

43. Joris, B., Ghuysen, J.-M., Dive, G., Renard, A., Dideberg, O., Charlier, P., Frère, J.-M. Kelly, J. A., Boyington, J. C., Moews, P. C. \& Knox, J. R. (1988) Biochem. J. 250, 313-324

44. Pugsley, A. P. \& Schwartz, M. (1985) FEMS Microbiol. Rev. 32, 3-38

Received 22 April 1991/30 May 1991; accepted 10 June 1991 